\title{
A Pedagogical View of English/Urdu Collocations
}

\author{
Saleem Akhter ${ }^{1}$, Behzad Anwar ${ }^{2} \&$ Abrar Qureshi $^{3}$ \\ ${ }^{1}$ University of Sargodha, Layalpur Campus, Faisalabad, Pakistan \\ ${ }^{2}$ University of Gujrat, Gujrat, Pakistan \\ ${ }^{3}$ University of Lahore, Pakpatan, Pakistan \\ Correspondence: Behzad Anwar, University of Gujrat, Gujrat, Pakistan. E-mail: behzad.anwar@uog.edu.pk
}

Received: November 9, 2017

Accepted: November 30, 2017 Online Published: December 23, 2017

doi:10.5539/ijel.v8n2p133

URL: http://doi.org/10.5539/ijel.v8n2p133

\begin{abstract}
To build a sound vocabulary and to give the basic knowledge of language to ESL students is one of the key issues for English language teachers in Pakistan. They emphasize single word vocabulary build-up along with grammatical construction of a sentence at the same time by making its Urdu translation without taking any considerable notice of the use of collocation (the naturally co-occurring words) not by chance but chosen by the native speakers consistently as a psycholinguistic consideration. This phenomenon results in the development of erroneous writing and speaking skills on the part of ESL students. So, the purpose of present study is to give a concrete description of English/Urdu collocations and to highlight the scope of English/Urdu collocations in Second Language Acquisition and Learning. A corpus based approach has been adopted to give the description of English/Urdu collocations based on contrastive analysis to point out the equivalent and non-equivalent collocations. The data is analyzed to emphasize the importance of teaching non-equivalent English/Urdu collocations to Pakistani students. This brief paper suggests the practical solutions of the present problem.
\end{abstract}

Keywords: English collocations, English in non-native context, ESL teaching and learning

\section{Introduction}

Teaching English vocabulary systematically to non-natives is a phenomenon faced by thousands of ESL (English as a Second Language) teachers around the world. This situation is further aggrieved when the second language learners of English have to deal with idioms and collocations; Fixed and relatively fixed lexical items.

The term collocation is ambiguous; the researchers have defined this phenomenon in different ways. For many it is re-current usage: "...English consists for the most part in the existence of so many odd comings-together-of-words" (Palmer, 1933), for others as a single lexical item (Halliday, 1964) and for a few it is a psychological phenomenon. However, in a more objective way it can be said that collocation is a combination of words in a language that occurs very often and more frequently than would happen by chance (OALD, 9th edition). Learning collocations is essential for ESL students.

Collocations fall into two major groups: lexical collocations and grammatical collocations (Benson, Benson, \& Ilson, 1986). Grammatical collocations are of equal importance as lexical collocations in ESL learning. Grammatical collocations perform important grammatical functions and their syntactical importance is undeniable but this study only focuses on lexical collocations and their role in vocabulary building from pedagogical perspective.

The interference of L1 in learning English can be a hindrance and a support to ESL learners; a hindrance as it leads to errors and can support because many rules and patterns of various languages are universal. There is a considerable shift from grammar to vocabulary learning during the last decade in English language teaching (Bahns, 1993). This step is a quite late but towards right direction because sound vocabulary enables the learners to get the comprehensive knowledge of how a language naturally works.

English collocations play a vital rule in vocabulary development and now it is widely accepted that this neglected field of study is very important for ESL learners. The phenomenon that collocations are mostly language specific and are difficult to learn make the ESL teachers perplexed and usually they avoid teaching collocations. The unavailability of the highly skillful teachers having native like control and cultural knowledge makes the situation more grieved. 
Most of ESL learners have to face problem in selecting the right collocational combination due to lack of collocational competence and L1 interference. Pakistani learners of English make similar kind of errors because they depend heavily on Urdu to learn English (Anwar, 2012). For example 'strong tea' is an acceptable collocational combination for native English speaker but the Urdu background ESL students will likely to use 'fast tea' due to L1 influence resulting in erroneous collocation patterns. However, in some cases the Urdu equivalents of English collocations like 'fast car' and 'scorching heat' are correct and acceptable collocational combinations.

It is a strong tradition to build English vocabulary through individual words in Pakistan. This tendency leads towards erroneous understanding of written and spoken discourse of English. To understand the meaning of text it is necessary to have knowledge of fixed and relatively fixed expression like idioms and collocations. To teach English collocations without the support of indigenous languages is not very difficult. So, it is essential to teach English collocations to Pakistani learners through L1 because without consistent support of indigenous languages, Pakistani learners of English cannot excel in vocabulary building.

Teaching English collocations to Pakistani learners of English without using Urdu or other local languages is a burdensome task on the part of ESL teachers, especially to those who have strong L1 background. This task can be eased by teaching indigenous equivalent and non-equivalent of English collocations.

\subsection{Statement of the Problem}

Teaching English collocations to build vocabulary of EFL and ESL learners is a neglected field of study in Pakistan. It requires support of indigenous languages to categorize equivalent and non-equivalent collocations. Although collocations are largely language specific (Maurer-Stroh, 2004) yet there are considerable number of equivalent collocations available in indigenous languages.

The ESL students in Pakistan are not taught collocations by using equivalents and non-equivalents Urdu/English patterns. The teachers can use this technique in teaching collocation to enhance the interest and learning of students. L1 should be used to facilitate ESL learning by categorizing the equivalents/non-equivalents patterns as non-equivalents are difficult to learn. Vocabulary building through English collocations requires highlighting and systematizing equivalent and non-equivalent collocations and ultimately to design activities based on this systematic study.

\subsection{Theoretical Background}

The theoretical background of the proposed research is based on CA (Contrastive Analysis); the study of similarities and differences across languages. Lado (1957) quoted in Gass \& Selinker (1983, p. 1) stated that "Individuals tend to transfer the forms and meanings and the distribution of forms and meanings of their native language and culture to the foreign language and culture - both productively and when attempting to speak the language and to act in the culture and receptively when attempting to grasp and understand the language and culture as practiced by natives". Similarly he (1957) stated that "those elements which are similar to [the learner's] native language will be simple for him, and those elements that are different will be difficult". Fries $(1945$, p . 9) mentioned that "The most efficient materials are those that are based upon a scientific description of the language to be learned, carefully compared with a parallel description of the native language of the learner".

Considering the above mentioned theory of Lado in which the differences across languages have more importance in contrastive analysis, the study of indigenous equivalent and non-equivalent collocations of English are based on contrastive analysis by utilizing the corpora of Urdu and English to find the similarities and differences in collocational pattering and eventually to develop a competence of correct collocational usage. Below-mentioned hypothesis that the non-equivalent collocation of English/Urdu are difficult and more important to learn than equivalent English/Urdu collocations further emphasizes the importance Lado's theory.

\subsection{Research Hypothesis}

Teaching of English collocations through indigenous languages especially Urdu will be beneficial for Pakistani learners. The categorization of equivalent and non-equivalent collocations from a pedagogical perspective will be highly supportive for Pakistani learners. It will enable them to use English more systematically and accurately. In fact, it will build a systematic vocabulary for learners.

The non-equivalent of English collocations will be difficult to learn and will have more pedagogical importance than equivalent of English collocations for Pakistani ESL students.

\subsection{Significance of Research}

Over the years, English collocations have got substantive place in ESL teaching. There is still no considerable 
work available on contrastive analysis of English/Urdu collocations from a pedagogical point of view. So, the main objectives of undertaking this research are to present systematic analysis and to point out the importance of teaching English collocation to Pakistani students who rely heavily on Urdu to learn English.

Teaching English collocations to Pakistani learners is a neglected field of study which results in erroneous use of the English language on the part of Pakistani students. To fill this gap and for systematic description of indigenous equivalent and non-equivalent of English collocations from a pedagogical point of view this study is very significant.

\subsection{Delimitation of Research}

There are many different indigenous languages spoken and understood in Pakistan as Urdu, Sindhi, Punjabi, Pushto, Saraiki, and Hindko etc. Therefore it is extremely hard to cover all these languages for indigenous equivalent and non-equivalent of English collocations. This study only focuses on English/Urdu contrastive lexical collocations from pedagogical perspective.

\section{Review of Related Literature}

Collocation is relatively a new phenomenon started with Firth and further developed by Sinclair when corpus based study had been adopted to find collocates. Actually Firth was the first person who proposed that the meaning is not restricted to one lexical unit (Firth, 1935). According to him, collocation or lexical meaning is one of the five dimensions of the meaning (phonetics, lexical, morphological, syntactic and semantic). Collocation is a lexical unit and very important to comprehend the meaning. So, the understanding of collocation "the company a word keeps" is very important along with phonological awareness, syntactic analysis, morphological breaks up and semantic relations to produce meaning which is required in translation and understanding of the given text. However, collocations are controversial because "...the boundaries between them and other multi-word lexical items do not always happen to be clear-cut" (Grimm, 2009, p. 23).

Therefore it is essential to sketch a clear boundary line among multi words constructions like idioms, collocations and free combinations. Idioms are frozen multi words and the constituent parts of idioms do not reflect the meaning of that particular idiom for example 'let the cat out of the bag' means to tell the secret with mistake. Collocations are relatively frozen and its meaning can be judged by its constituent parts but these combinations occur more often than by chance for example 'crying shame' is an English collocation. Other free combinations are loosely constructed and their constituent parts can be changed or altered to produce similar kind of effect or meaning.

The recent study is inspired by two significance works on collocations (Bahns 1993; Awan \& Qureshi 2014). Bahns emphasized on contrastive study of English and German lexical collocations. He stated that the collocations are in thousands. This load of teaching collocations can be reduced if a contrastive approach towards collocations is adopted. His emphasis was more on non-equivalent English/German collocations and he considered them more important from EFL teaching point of view. Awan \& Qureshi (2014) divided the Urdu collocations into four types as unrestricted, semi restricted, restricted and inherent collocation.

So, it is important to systematize indigenous equivalent of English collocations to ease the learning of English collocations for Pakistani student. On the basis of practical implementations of these two studies, it is important to take a contrastive approach towards teaching English collocations to build the vocabulary of learners.

\section{Methodology}

The most accurate way to find the indigenous equivalent and non-equivalents of English collocation is to use the corpus of indigenous languages. The use of corpus has revolutionized the study of frequency based collocates in English and almost all the possible collocational structures, combinations and usage have been identified and brought in to the light with the use of specific corpus analysis software tools like Wordsmith, Antconc etc.

Newspaper corpus of 3 million words has been compiled to check the Urdu equivalent/non-equivalent of English collocations as the actual usage of words in a real setting can give us the exact description of collocated words. The following two Pakistani Urdu language newspapers were selected to compile the Urdu corpus:

1) Nawaiwaqt (May, 2015)

2) Jang (May, 2015)

The news from all the genres of above-mentioned newspapers were copied in the notepad. Unicode utf- 8 language encoding was used for data analysis. Antonc was used to extract the examples of collocations. The researchers have used the Oxford Collocations Dictionary as a source to check the collocations of Urdu equivalents. 
The following diagrams show that Wordsmith/Antconc software is helpful to use corpus for finding concordance. English and Urdu collocations are apparent in these diagrams. So, it is easy to know the habitually co-occurrence of words by using corpus.

\begin{tabular}{|c|c|c|c|c|c|c|c|c|}
\hline \multicolumn{2}{|c|}{ Concordance } & Concordance Plot & File View & Clusters & Collocates & Word List & & \\
\hline Hit & KWIC & & & & & & & \\
\hline \multicolumn{9}{|c|}{\begin{tabular}{l||l} 
blot on the repeated and tall claims of democracy. Very recent: & top story $1-m a$ \\
e added that those making tall claims of providing protection to \\
nment, instead of making tall claims, should practically execute \\
he blasts, despite making tall claims regarding National Action \\
kadded that those making tall claims of providing protection to \\
top story.txt \\
national.txt \\
ore a safe city. As usual tall claims were made to bring the tel \\
he blasts, despite making tall claims regarding National Action \\
pakhtunkhwa governments tall claims for promotion of education \\
karachi.txt \\
lahore $4 . t x t$ \\
national.txt \\
$13 a p r . t x t$
\end{tabular}} \\
\hline
\end{tabular}

Figure 1. Pakistani English Newspaper Corpus

\begin{tabular}{|c|c|}
\hline \multirow{2}{*}{\multicolumn{2}{|c|}{$\begin{array}{l}\text { Concordance } \mid \text { Concordance Plot } \mid \text { File View } \mid \text { Clusters } \\
\text { Hit } \mid \text { Collocates }\end{array}$}} \\
\hline & \\
\hline 1 & 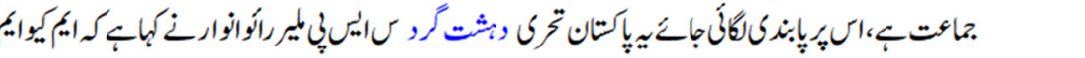 \\
\hline 2 & 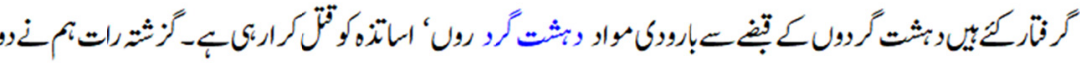 \\
\hline 3 & 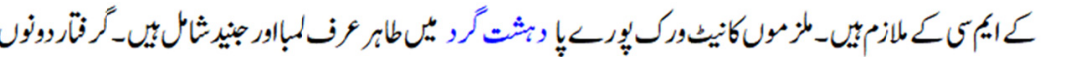 \\
\hline 4 & 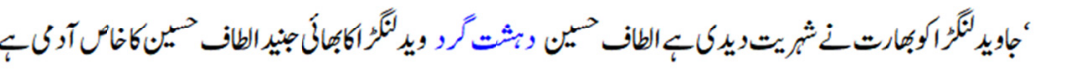 \\
\hline 5 & 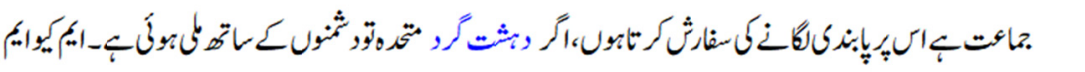 \\
\hline 6 & 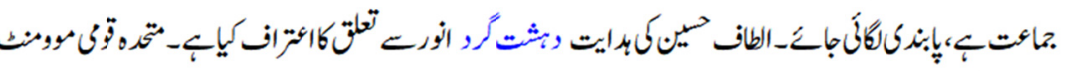 \\
\hline 7 & 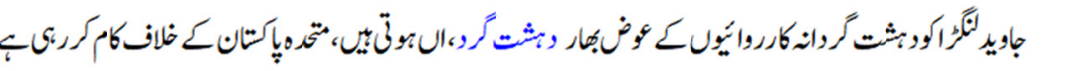 \\
\hline 8 & 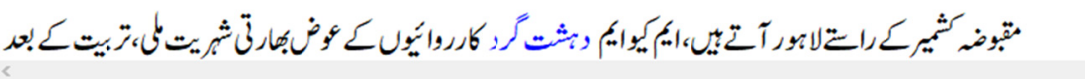 \\
\hline
\end{tabular}

Figure 2. Pakistani Urdu Newspaper Corpus

\begin{tabular}{|c|c|}
\hline \multicolumn{2}{|r|}{ 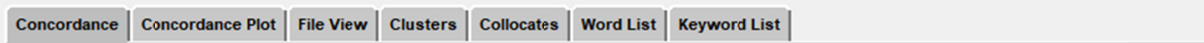 } \\
\hline Hit & kmic \\
\hline 1 & 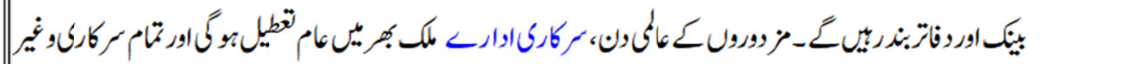 \\
\hline 2 & 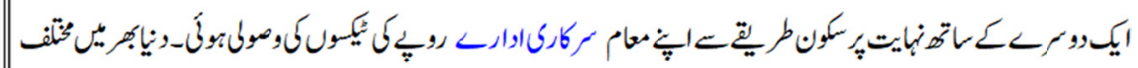 \\
\hline 3 & 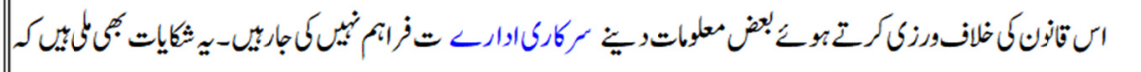 \\
\hline 4 & 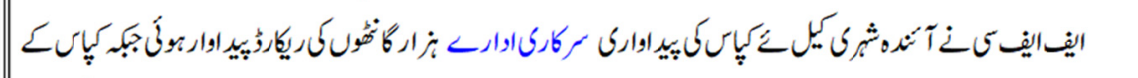 \\
\hline 5 & 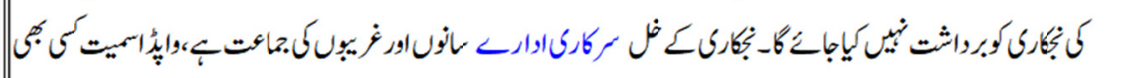 \\
\hline 6 & 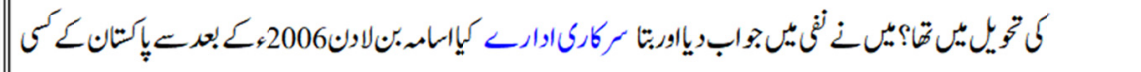 \\
\hline 7 & 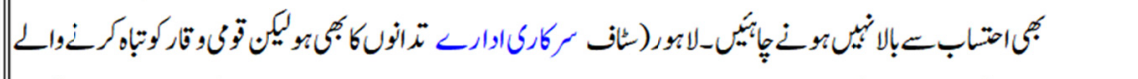 \\
\hline 8 & 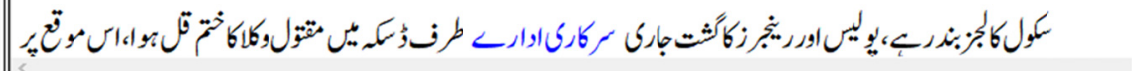 \\
\hline
\end{tabular}

Figure 3. Pakistani Urdu Newspaper Corpus 


\section{Data Analysis}

The data has been analyzed keeping in view the Urdu equivalent/non-equivalents of English collocations. Collocations fall into two major groups; lexical collocations and grammatical collocations (Benson, Benson \&Ilson, 1986). Lexical collocations are combination of open word class and show the following possible structures:
(1) Adjective + noun
heavy smoker, strong tea
(2) Noun + verb negotiation collapse, prices fall
(3) Verb + noun commit a crime, give a lecture
(4) Verb + adverb meditate deeply, defend vigorously
(5) Adverb + adjective readily available, perfectly capable
(6) Noun + Noun game of chess

On the other hand, grammatical collocations are combination of close class along with one open class and used to perform important grammatical functions for example: to be attracted to etc. In vocabulary building the role of lexical collocations is more significant than that of grammatical collocation.

The possible structures of English lexical collocations can be found in Urdu and other indigenous languages of Pakistan. The following examples will illustrate this phenomenon with reference to Urdu:
(1) Adjective + noun
تيز كازى، خوبصورت لزركى
(2) Noun + verb
قيمت برّهى
(3) Noun + verb
جرم كرنا
(4) Adverb + verb
سختى سـ كجلنا
(5) Adverb + adjective
مكمل مابر
(6) Noun + Noun
شطرنج كا كهيل

The Urdu lexical collocation structures of Noun + Verb and Adverb + Verb are entirely opposites of English lexical collocational structures of Verb + Noun and Verb + Adverb but the remaining lexical constructions of English/Urdu collocations are the same.

Although in Urdu $\mathrm{N}+\mathrm{V}$ and in English $\mathrm{V}+\mathrm{N}$ and similarly Adverb $+\mathrm{V}$ and $\mathrm{V}+$ Adverb constructions of collocations are opposite but by presenting substitutional word class of equivalent collocations can give accurate understanding to Pakistani ESL students as the following tables illustrate:

Table 1. English/Urdu equivalent collocation (noun and verb)

\begin{tabular}{|c|c|c|c|c|c|}
\hline \multicolumn{3}{|c|}{ English Collocation } & \multicolumn{3}{|c|}{ Urdu Collocation } \\
\hline Verb & Noun & $\mathrm{V}+\mathrm{N}$ & Noun & Verb & $\mathrm{N}+\mathrm{V}$ \\
\hline commit & a crime & Commit a crime & جرم & كرنا & جرم كرنا \\
\hline
\end{tabular}

Table 2. English/Urdu equivalent collocation (verb and adverb)

\begin{tabular}{|c|c|c|c|c|c|}
\hline \multicolumn{3}{|c|}{ English Collocation } & \multicolumn{3}{|c|}{ Urdu Collocation } \\
\hline Verb & Adverb & V+ Adverb & Adverb & Verb & Adverb + V \\
\hline Defend & vigorously & Defend vigorously & بمت سـ & دفاع كرنا & بمت سـ دفاع كرنا \\
\hline
\end{tabular}

Similarly presenting equivalent and non-equivalent of English collocations in Urdu in a systematic way will enhance the vocabulary as well as increase the competence level of learners to use English collocations correctly. Following tables illustrate the point: 
Table 3. Equivalent of English collocations in Urdu

\begin{tabular}{|c|c|}
\hline English Collocations & Equivalent Urdu collocations \\
\hline Adverse effects & برح اثرات \\
\hline Beam of light & روشنى كى كرن \\
\hline Break the law & 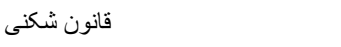 \\
\hline Break the silence & خاموشى توزُنا \\
\hline Commit a crime & 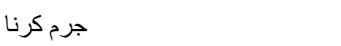 \\
\hline Fast car & 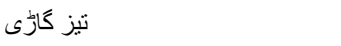 \\
\hline Make a mistake & 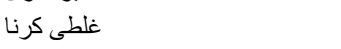 \\
\hline Painfully slow & تكليف ده حد تكى سست \\
\hline Scorching heat & مجلجاتى دهوبٍ \\
\hline
\end{tabular}

Table 4. Non-Equivalent of English collocations in Urdu

\begin{tabular}{|c|c|c|}
\hline English Collocations & Literally translated & Non-Equivalent Urdu Collocations \\
\hline Bend the rules & قو انين كو جهكانا & 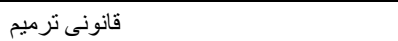 \\
\hline Deeply ashamed & كَبرى شر مندكى & بـ حد شرمندگى \\
\hline Drop a hint & 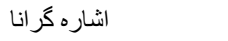 & 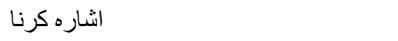 \\
\hline Lose your patience & صبر كهونا & بـه صبرى، به جينى \\
\hline Make a choice & انتخاب بنانا & ا انتخاب كرنا \\
\hline Promising start & 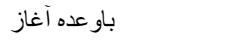 & اجهها آغاز \\
\hline Resounding success & كُونجنى كاميابى & بهت برُى كاميابى \\
\hline Significant number & شاندار عدد & بيت بزّى تعداد \\
\hline Strong tea & مضبوط جائح & تيز جائح \\
\hline Thick fog & موثُى دهند & شديد دهند \\
\hline
\end{tabular}

Firstly, English collocation of table 3 are easy to teach to Urdu background ESL learners but the collocations of table 4 without non-equivalent of English collocations will get tricky and result in erroneous use of English collocations. Instead of giving literal translation to the learners there is a need of making these non-equivalents as substitutional or balanced English collocations in Urdu to help the ESL learners.

Secondly, the Urdu collocations including verb have inflectional ending like بينا كرنا، نورزنا , etc. These inflectional ending of Urdu verbs are not possible in English collocations and also the Urdu collocations including adverbs consist of more than two words as in مكمل طور بر ابل and تكليف ده حد تك سست. So, it is essential to categorize Urdu collocations on frequency basis by using corpus of the Urdu language to solve this problem.

\section{Conclusion}

The findings of this study suggest that collocations are very problematic for ESL learners but if there is a systematic categorization of indigenous equivalent and non-equivalent of English collocations, learning in ESL can be facilitated. The importance of teaching English collocations to EFL and ESL learners is essential not only to build their vocabulary but also to enhance competence of the English language among learners. This brief paper can conclude the following points based on the above-mentioned discussion; Firstly, the systematic analysis of indigenous equivalents of English collocations is indispensable to support Pakistani English teachers who always shied away from teaching English collocations. Secondly, categorization is also necessary because collocations are largely language specific and are thousands in numbers. Thirdly, the teachers must design activities based on the results to give practical support to the hypothesis.

This study will also open new horizons for future researchers who are interested in contrastive analysis, lexicology, lexicography, translation and other similar kind of fields.

\section{References}

Anwar, B. (2012). A Sociolinguistics Study of Urdu-English Code-switching in Pakistan. Unpublished Ph.D. Thesis. Bahauddin Zakariya University, Multan.

Awan, M. A., \& Qureshi, A. H. (2014). Computational Description of Urdu Collocations. International Journal of English and Education.

Bahns, J. (1993). Lexical Collocations: A Contrastive View. ELT Journal, 47(1), 56-63. https://doi.org/10.1093/elt/47.1.56

Benson, M., Benson, E., \& Ilson, R. (1997). The BBI Dictionary of English Word Combinations. Amsterdam and 
Philadelphia: John Benjamins Publishing Company. [Rev. edn. of: The BBI Combinatory Dictionary of English. 1986]. https://doi.org/10.1075/z.bbi1(2nd)

Bloomfield, L. (1933). Language. New York: Henry Holt.

Carter, R. (1998). Vocabulary. Applied Linguistic Perspective (2nd ed.). London and New York: Routledge. https://doi.org/10.4324/9780203270110

Carter, R., \& McCarthy, M. (1988). Vocabulary and Language Teaching. London: Longman.

Firth, J. R. (1951). Modes of Meaning Essays and Studies. The English Association, 118-149.

Firth, J. R. (1957). Papers in Linguistics 1934-1951. London: Oxford University Press.

Fries, C. (1945). Teaching and Learning English as a Foreign Language. Ann Arbor, Michigan: University of Michigan Press.

Gass, S., \& Selinker, L. (1983). Language Transfer in Language Learning. Rowley, Mass.: Newbury House.

Grimm, S. P. (2009). Collocation in Modern Standard Arabic Revisited. Journal of Arabic Linguistics, 51, 22-41.

Halliday, M. A. K. (1966). Lexis as a Linguistic Level. In C. E. Bazell et al. (Eds.), In Memory of J. R. Firth. Longman, London.

Jackson, H., \& Amvela, E. Z. (1999). Words, Meaning and Vocabulary: An Introduction to Modern English Lexicology. New York: Continuum.

Lado, D. R. (1957). Linguistics Across Cultures. Ann Arbor: University of Michigan Press.

Lado, D. R., \& Fries, C. C. (1943). English Pattern Practices. University of Michigan Press.

Maurer-Stroh, M. P. (2004). Towards a Bilingual Adjective-Noun Collocation, Dictionary of English and German. Unpublished Ph.D dissertation. University of Klagenfurt, Klagenfurt.

Oxford Advanced Learner's Dictionary. (9th ed.). Oxford: Oxford University Press.

Palmer, H. E. (1933). Second Interim Report on English Collocations. Tokyo: Kaitakusha Press.

Shammas, D. N. (2013). Collocation in English: Comprehension and Use by MA Students at Arab Universities. International Journal of Humanities and Social Science, 3, 9.

Sinclair, J. (1991). Corpus, Concordance, Collocation. Oxford: Oxford University Press.

\section{Copyrights}

Copyright for this article is retained by the author(s), with first publication rights granted to the journal.

This is an open-access article distributed under the terms and conditions of the Creative Commons Attribution license (http://creativecommons.org/licenses/by/4.0/). 